\title{
MINIMIZATION OF TOXIC EMISSIONS DURING BURNING LOW-GRADE FUEL AT KAZAKHSTAN THERMAL POWER PLANT
}

\author{
Aliya Askarova $^{a, b}$, Pavel ŠafaříK ${ }^{c}$, Aizhan Nugymanova $^{a, *}$, \\ Saltanat Bolegenova $^{a, b}$, VAleriy Maximov ${ }^{b}$, Symbat Bolegenova ${ }^{a}$ \\ a al-Farabi Kazakh National University, Faculty of Physics and Technology, al-Farabi Ave, 050040 Almaty, \\ Kazakhstan \\ ${ }^{b}$ al-Farabi Kazakh National University, Scientific Research Institute of Experimental and Theoretical Physics, \\ Tole bi 94a, 480012 Almaty, Kazakhstan \\ ${ }^{c}$ Czech Technical University in Prague, Faculty of Mechanical Engineering, Department of Fluid Dynamics and \\ Thermodynamics, Technická 4, 16607 Prague, Czech Republic \\ * corresponding author: nugymanova.aizhana@gmail.com
}

Abstract. This paper presents new results of computational experiments on the implementation of Overfire Air (OFA) technologies using an example of a combustion chamber of the BKZ-75 boiler of the Shakhtinskaya power plant (Shakhtinsk, Kazakhstan) burning high-ash Karaganda coal. The effect of mass air flow through special nozzles located above the burner level on the flow aerodynamics, temperature fields, concentration fields of carbon monoxide $\mathrm{CO}$ and nitrogen $\mathrm{NO}$ over the entire volume of the combustion chamber was studied. The studied characteristics were compared for various percentages of supplying additional air through OFA injectors: OFA is $0 \%$ (basic version), $10 \%$ and $18 \%$. It was shown that the installation of OFA injectors leads to a change in the field of the total velocity vector, temperature, and concentrations of carbon oxides and nitrogen. An increase in the percentage of air supplied through OFA injectors to $18 \%$ leads to a decrease in the concentrations of carbon monoxide $\mathrm{CO}$ by about $36 \%$ and nitrogen oxide NO by $25 \%$ compared with the base case. The obtained results will optimize the process of burning pulverized fuel in the combustion chamber of the BKZ-75 boiler, increase the efficiency of fuel burnout, reduce harmful emissions and introduce OFAtechnology at other coal-burning thermal power plants.

KEYWORDS: Heat and mass transfer, combustion, numerical simulation, stepwise combustion (OFA), aerodynamics, temperature, carbon oxides and nitrogen.

\section{INTRODUCTION}

In most economically developed countries of the world, as in Kazakhstan, a significant amount of thermal and electric energy is generated at thermal power plants (TPPs) burning organic fuel. The main fuel for Kazakhstan's TPPs is coal, which has a significant moisture content and relatively low calorific value, as well as a high content of ash (more than $40 \%$ ) and sulfur [1-6]. Given the large amount of cheap Kazakh coal and a complex of large coal-fired power plants over the next two decades, it is expected that the Republic will rely heavily on coal fuel [7-10].

The use of low-grade fuel with high ash content places high demands on the reliability of the boiler plants of TPPs, as well as on ensuring strict environmental requirements for the emissions of carbon monoxide CO and nitrogen NO [11-15]. Currently, the share of emissions from sources of the energy complex of Kazakhstan with its high dependence on coal as the main source of energy is $43.7 \%$ of all emissions of pollutants into the air in Central Asia. For this purpose, the development and implementation of environmentally friendly technologies for the combustion of solid fuels in the furnaces of boilers of Kazakhstan TPPs are relevant [16 20].

At present, a large number of measures have been developed and implemented to tighten the requirements for harmful emissions of thermal power plants, the most dangerous of which are nitrogen oxides. There are various methods for reducing emissions of nitrogen oxides [21 27], the most appropriate of which is the introduction of technology for suppressing nitrogen oxides at the stage of the fuel combustion in the combustion chamber. Stepwise fuel combustion Overfire Air (OFA) technology is one of the most effective methods to reduce the concentration of nitrogen oxides NOx [28, 29].

The stepwise air supply to the combustion chamber with OFA- technology consists in supplying the required amount of air for the burning coal as follows: 70-90\% air is supplied to the burners and 10-30\% through the OFA injectors located above the burners. In this case, a low-temperature oxygen-depleted and fuel-rich combustion zone is created in the lower part of the combustion burner, which reduces the formation of NOx from fuel nitrogen (fuel NOx). At the 
same time, the low temperature in the oxygen enriched zone of OFA injectors minimizes the formation of NOx from the air (thermal NOx) [30, 31.

The reconstruction of Kazakhstan TPPs, testing of commissioning works by means of industrial tests with the implementation of the Overfire Air (OFA) technology described above have significant limitations due to the high complexity and high cost. In this regard, the main methods for studying the processes occurring in the combustion chambers of thermal power plants are numerical modeling methods and the implementation of computational experiments based on them that adequately reflect the real physical processes occurring in the combustion chambers 32 39.

The purpose of this work is to introduce Overfire Air technologies using the latest information technologies and $3 \mathrm{D}$ computer simulation methods using the example of the combustion chamber of the BKZ-75 boiler of the Shakhtinskaya TPP. This will optimize the processes that occur during the burning of highash energy fuel, reduce harmful dust and gas emissions into the atmosphere and create and implement a way to produce a "clean" energy at other coal-fired TPPs in the future.

\section{OBJECT OF STUDY}

For conducting numerical experiments on the implementation of OFA technologies, the combustion chamber of the BKZ-75 boiler of the Shakhtinskaya TPP (Shakhtinsk, Kazakhstan) was selected. Boiler BKZ75 has a height of $16.75 \mathrm{~m}$, a depth of $6.6 \mathrm{~m}$, a width of $6 \mathrm{~m}$, a vertical water-tube structure; it has a U-shaped scheme for the movement of the working medium, based on natural circulation through the drum. The boiler is equipped with four pulverized coal burners which are installed in two on the front and back walls in one tier. The boiler BKZ-75 of the Shakhtinskaya THP plant uses the dust of the Karaganda coal grade KR-200 with ash-content of $35.1 \%$, volatile yield of $22 \%$, humidity of $10.6 \%$ and gross calorific value of $18.55 \mathrm{MJ} / \mathrm{kg}$. The boiler is equipped with four burners installed, two burners from the front and from the rear in one tier at a height of $z=4 \mathrm{~m}$, and four OFA injectors at a height of $z=9.4 \mathrm{~m}$. A more detailed description of the boiler's combustion chamber, mathematical model, solution method and the application software package is given in the following works [4048. General view of the combustion chamber of the BKZ-75 boiler, the layout of the burners and OFA injectors are shown in Figure 1 For numerical simulation, a finite-difference grid was selected (Figure 1 a), which is 455040 control volumes.

Various percentages of supplying additional air through OFA injectors were investigated: OFA $=0 \%$ (basic version), $\mathrm{OFA}=10 \%, \mathrm{OFA}=18 \%$. Flow aerodynamics (distribution of the overal velocity vector), temperature fields, concentration fields of carbon monoxide $\mathrm{CO}$ and nitrogen oxide $\mathrm{NO}$ over the entire volume of the combustion chamber were obtained, and

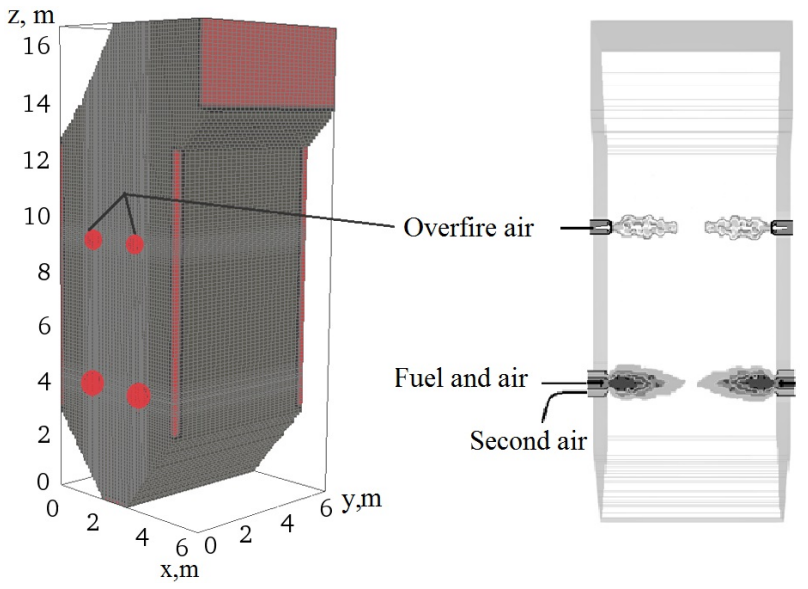

FiguRE 1. General view of the combustion chamber of the BKZ-75 boiler of the Shakhtinskaya TPP, a) its breakdown into control volumes and $b$ ) the layout of OFA burners and injectors.

a comparative analysis was performed for the studied modes.

\section{Results}

Figures 2 and 3 show the distribution of the overal velocity vector in the region of the location of the burners $(z=4 \mathrm{~m})$ and OFA injectors $(z=9.4 \mathrm{~m})$ for the base case $(\mathrm{OFA}=0 \%)$ and using the Overfire Air technology $(\mathrm{OFA}=18 \%)$. An analysis of the figures shows that for these two investigated percentages of air supply through OFA nozzles, the torch core is located in the centre of the combustion chamber and is determined by the region of the collision of flows from the burners.

Figure 4 shows the temperature distribution in the area of the burners for the base case $(\mathrm{OFA}=0 \%)$ and using the technology of Overfire Air (OFA $=10 \%$, OFA $=18 \%$ ). An analysis of Figure 4 shows that with an increase in the volume of the air supplied through the injectors OFA, the temperature in the centre of the combustion chamber increases: for $\mathrm{OFA}=0 \% t_{c c . c h}=620.6^{\circ} \mathrm{C} ; \mathrm{OFA}=10 \%$ $t_{\text {cc. } . c h .}=750.3^{\circ} \mathrm{C} ; \mathrm{OFA}=18 \% t_{\text {cc. } . c h .}=744.1^{\circ} \mathrm{C}$. This is due to the fact that with the OFA, the area around the burners is depleted in oxygen, which leads to a decrease in the coefficient of excess air. On the contrary, more air is supplied in the area of the location of OFA injectors, chemical reactions occur more intensively and the temperature rises: for $\mathrm{OFA}=0 \%$ $t_{\text {cc.ch. }}=987.31^{\circ} \mathrm{C} ; \mathrm{OFA}=10 \% t_{\text {cc.ch }}=918.56^{\circ} \mathrm{C}$; $\mathrm{OFA}=18 \% t_{c c . c h}=879.17^{\circ} \mathrm{C}$ (Figure 5).

This temperature behaviour is clearly seen in the Figure 6, where the temperature distribution $T$ over the height of the boiler combustion BKZ-75 is presented for various percentages of air supplied through OFA injectors. At the outlet of the combustion chamber, we have a further decrease in temperature: $\mathrm{OFA}=0 \%-885.80{ }^{\circ} \mathrm{C} ; \mathrm{OFA}=10 \%-865.91{ }^{\circ} \mathrm{C}$; $\mathrm{OFA}=18 \%-856.27^{\circ} \mathrm{C}$. The temperature at the 

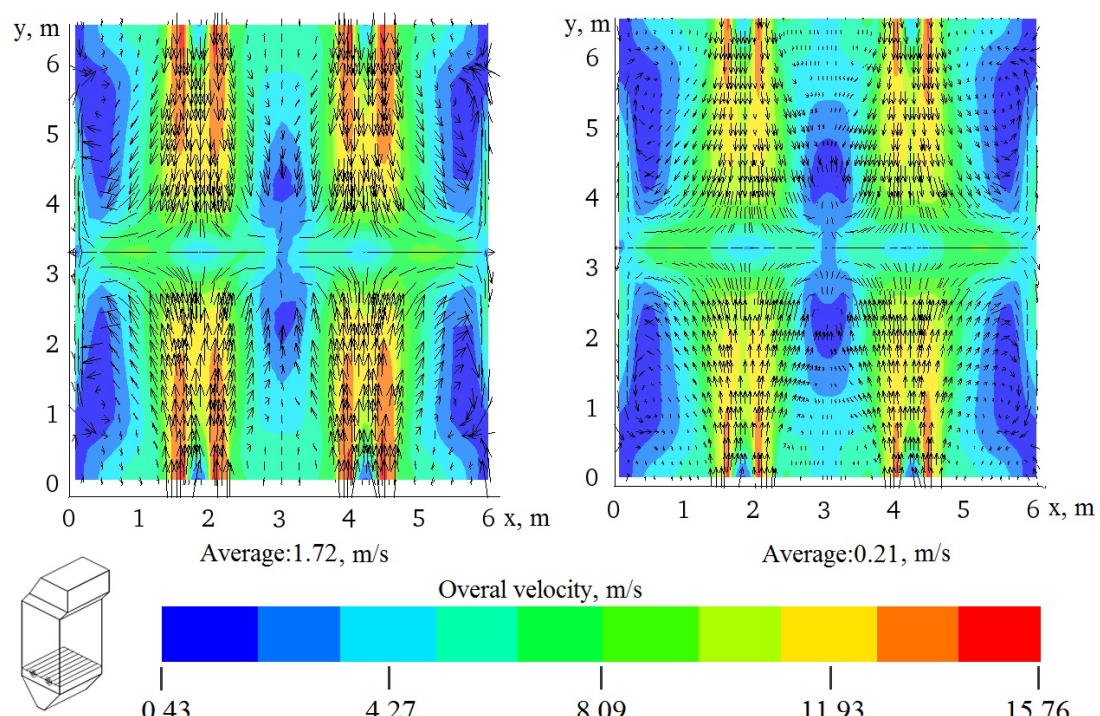

Overal velocity, $\mathrm{m} / \mathrm{s}$

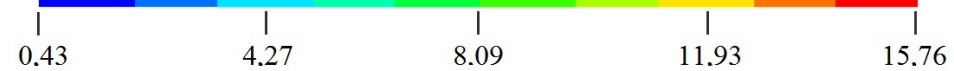

FiguRE 2. The field of the overal velocity vector in the area of the arrangement of the burners for various percentages of air supplied through the injectors: a) OFA $=0 \%$ (basic version), b) OFA $=10 \%$.
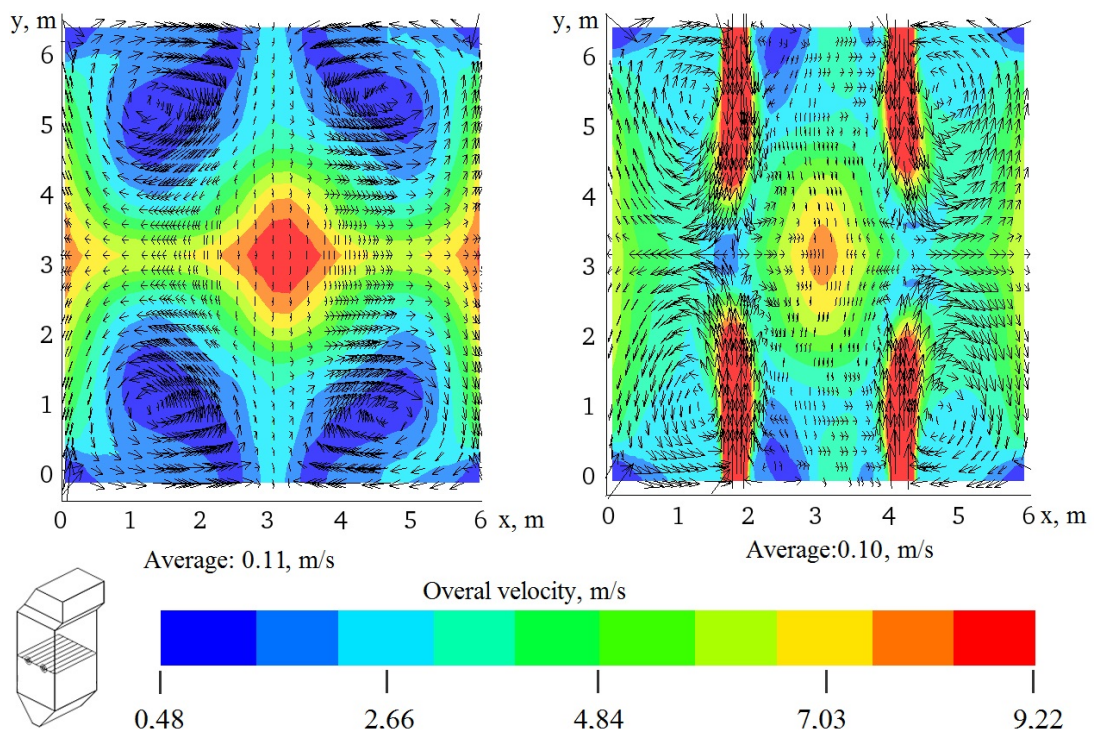

Overal velocity, $\mathrm{m} / \mathrm{s}$

FigURE 3. The field of the overal velocity vector in the region of the arrangement of OFA injectors for various percentages of air supplied through injectors: a) OFA $=0 \%$ (basic version), b) OFA $=10 \%$.
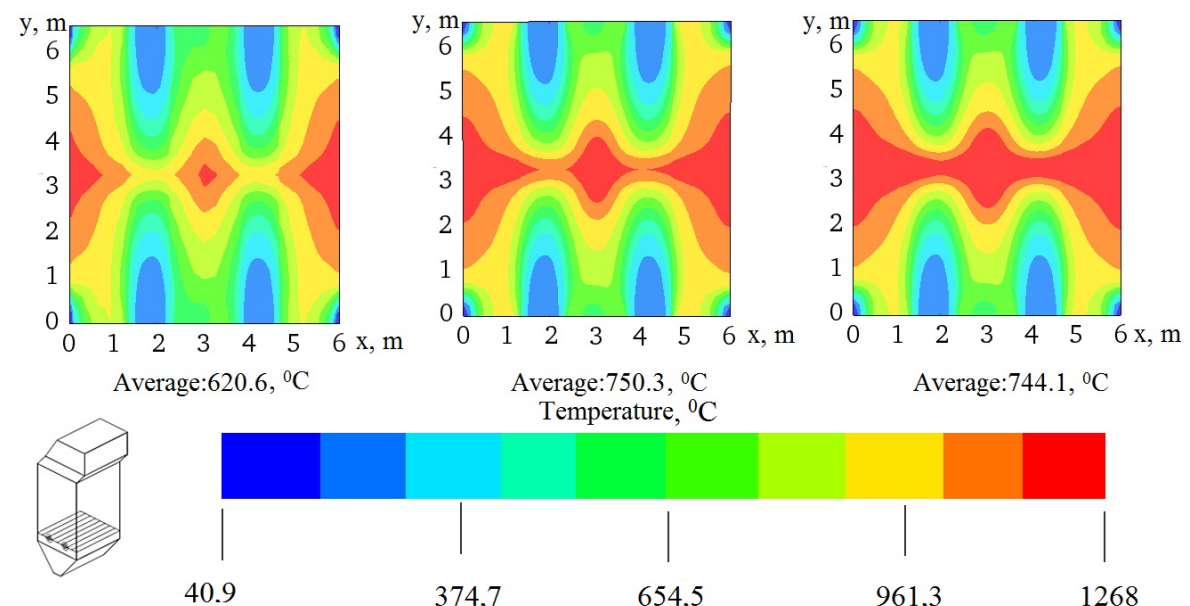

FigURE 4. Temperature distribution in the area of burner arrangement for various percentages of air supplied through injectors: a) $\mathrm{OFA}=0 \%$ (basic version), b) OFA $=10 \%, \mathrm{c}$ ) $\mathrm{OFA}=18 \%$. 

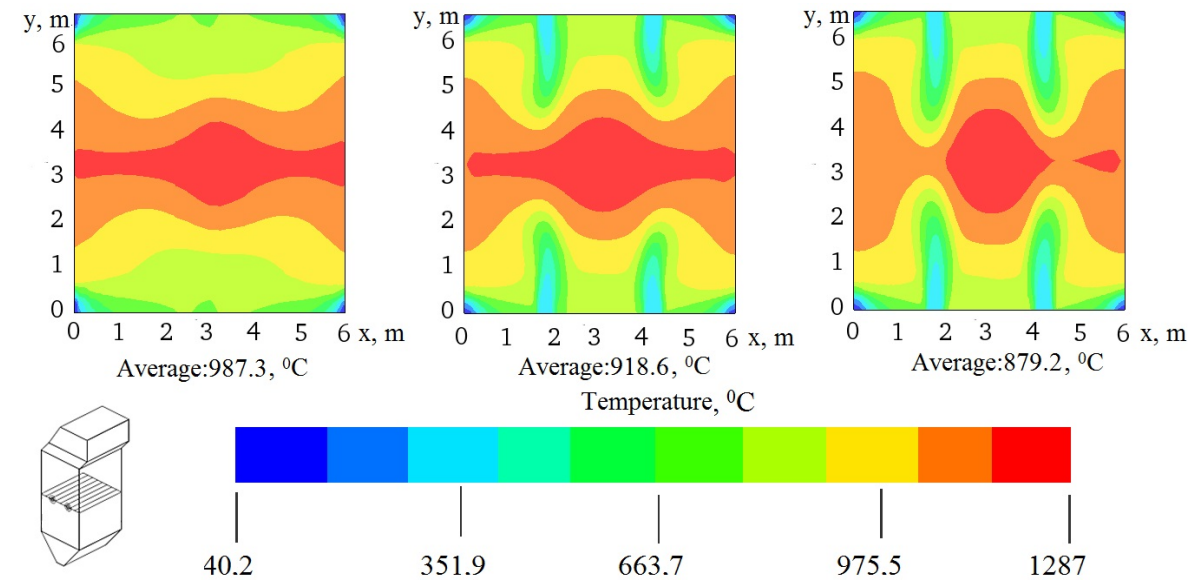

FigURE 5. Temperature distribution in the area of the location of OFA injectors for various percentages of air supplied through injectors: a) OFA $=0 \%$ (basic version), b) OFA $=10 \%$, c) OFA $=18 \%$.

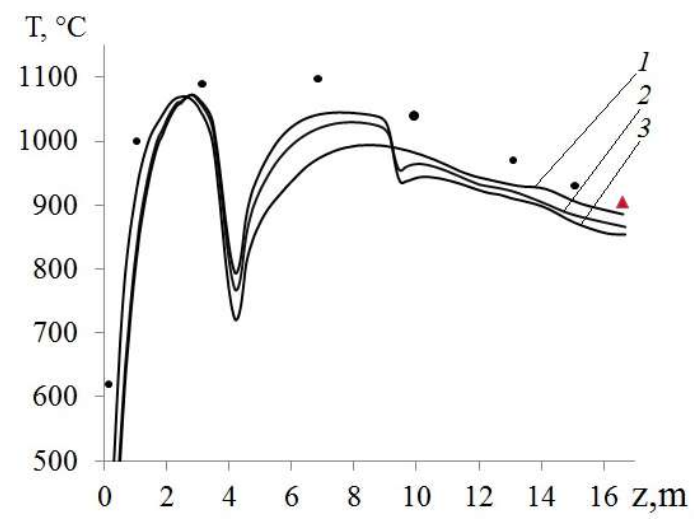

Figure 6. Temperature distribution $\mathrm{T}$ along the height of the combustion chamber of the boiler BKZ-75 at various percentages of air supplied through injectors OFA: $1-$ OFA $=0 \%$ (basic version), $2-$ OFA $=10 \%$, $\mathrm{OFA}=18 \%$; "black circle" - experiment at TPP 49; "red triangle" - is theoretical values obtained by the method of thermal calculation CBTI - Central Boilerand-Turbine Institute [50.

outlet of the combustion chamber is confirmed by experimental data directly at the TPP [49] and its theoretical value calculated by the CBTI method for the base case [50].

Figures 7 and 8 below illustrate two-dimensional distributions of the concentration of carbon monoxide $\mathrm{CO}$ in the area of the arrangement of burners and OFA injectors for three options for supplying additional air: a) $\mathrm{OFA}=0 \%$ (basic version), b) $\mathrm{OFA}=10 \%, \mathrm{c}$ ) $\mathrm{OFA}=18 \%$.

It can be noted that carbon monoxide is concentrated mainly in the zone of the main distribution of the fuel flow and oxidizer (air) from the burners, i.e. where there is a large amount of carbon fuel. With an increase in the volume of air supplied through OFA injectors, further oxidation of carbon monoxide $\mathrm{CO}$ to carbon dioxide $\mathrm{CO}_{2}$ occurs, which leads to a decrease in $\mathrm{CO}$ in the exhaust gases and at the outlet from the combustion space (Figure 9). Analysis of the figure shows that an increase in the volume of air supplied through OFA injectors allows to reduce the concentration of carbon monoxide $\mathrm{CO}$ at the outlet of the combustion chamber from $7.3 \cdot 10^{-4} \mathrm{~kg} / \mathrm{kg}$ to $4.6 \cdot 10^{-4} \mathrm{~kg} / \mathrm{kg}$, which is about $36 \%$.

Distributions of nitrogen oxide NO concentration along the height of the combustion chamber, in the area of the arrangement of burners and OFA injectors and for three options for supplying additional air through injectors: a) OFA $=0 \%$ (basic version), b) $\mathrm{OFA}=10 \%$, c) $\mathrm{OFA}=18 \%$ are presented in Figures 10, 11 and 12. It is shown that an increase in the volume of the air supplied through the injectors reduces the concentration of nitrogen oxides $\mathrm{NO}$ at the outlet of the furnace space. So at OFA $=18 \%$, the concentration of nitrogen oxide $\mathrm{NO}$ at the outlet of the combustion chamber is $277.12 \mathrm{mg} / \mathrm{nm}^{3}$, which is about $25 \%$ lower than in the base case, where the concentration of nitrogen oxide is $368.08 \mathrm{mg} / \mathrm{nm}^{3}$.

The maximum permissible concentration for nitrogen oxides NO, adopted in the Republic of Kazakhstan, is $850 \mathrm{mg} / \mathrm{nm}^{3}$. Thus, we can conclude that the introduction of OFA technology on the BKZ-75 boiler of the Shakhtinskaya TPP allows to significantly reduce emissions of harmful substances (carbon oxides $\mathrm{CO}$ and nitrogen NO) and extend the results to the implementation of this technology on other coal-fired TPPs.

\section{Conclusions}

Computational experiments have been performed to study the characteristics of heat and mass transfer (flow aerodynamics, temperature and concentration fields) with the introduction of the OFA technology in the combustion chamber of the BKZ-75 boiler of the Shakhtinskaya TPP burning high-ash karaganda coal. The effect of various percentages of supplying additional air through the injectors was studied: OFA is $0 \%$ (basic version), $10 \%$ and $18 \%$.

It was shown that the installation of additional nozzles for air above the level of the burners leads to 

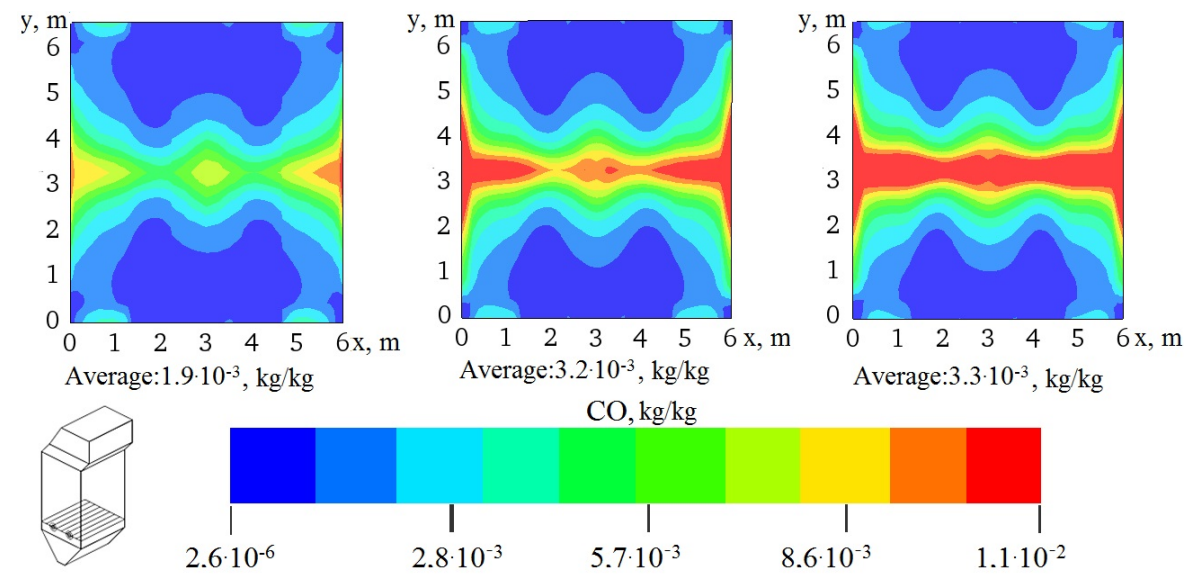

FIgURE 7. The distribution of the concentration of carbon monoxide CO in the area of the location of the burners for different volumes of air supplied through the injectors: a) OFA $=0 \%$ (basic version), b) OFA $=10 \%$, c) $\mathrm{OFA}=18 \%$.
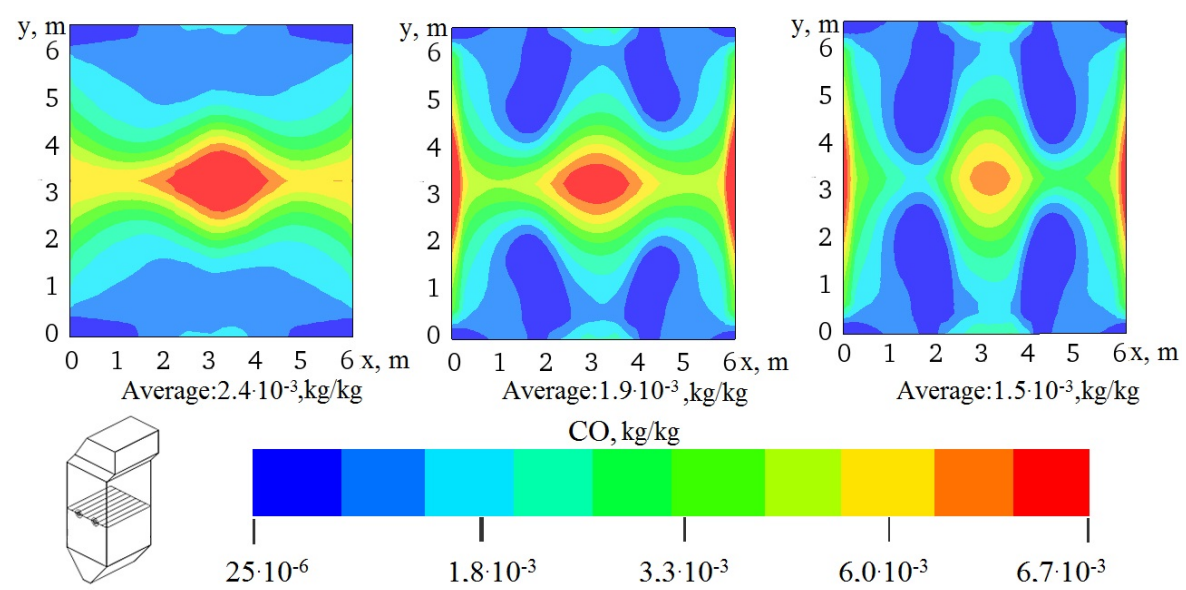

Figure 8. The distribution of the concentration of carbon monoxide CO in the area of the location of OFA injectors at various percentages of air supplied through injectors: a) OFA $=0 \%$ (basic version), $\mathrm{b}$ ) $\mathrm{OFA}=10 \%, \mathrm{c}$ ) $\mathrm{OFA}=18 \%$.

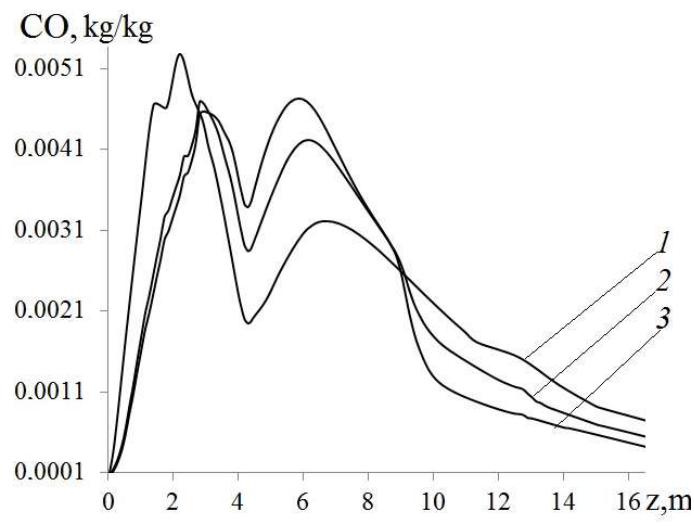

Figure 9. The distribution of the concentration of carbon monoxide $\mathrm{CO}$ at the outlet of the combustion chamber of the boiler BKZ-75 at various percentages of air supplied through OFA injectors: a) OFA $=0 \%$ (basic version), b) OFA $=10 \%, \mathrm{c}) \mathrm{OFA}=18 \%$.

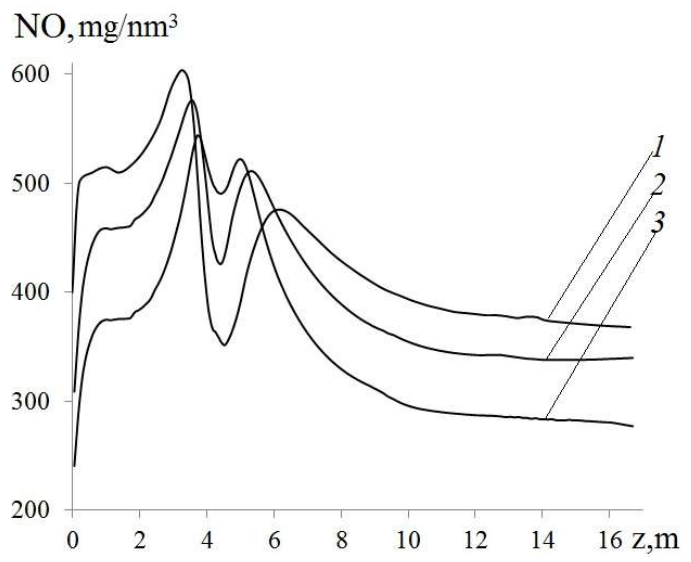

FiguRE 10. Distribution of the concentration of nitrogen oxide NO along the height of the combustion chamber of the BKZ-75 boiler at various percentages of air supplied through OFA injectors: a) OFA $=0 \%$ (basic version), b) OFA $=10 \%, \mathrm{c}$ ) $\mathrm{OFA}=18 \%$. 

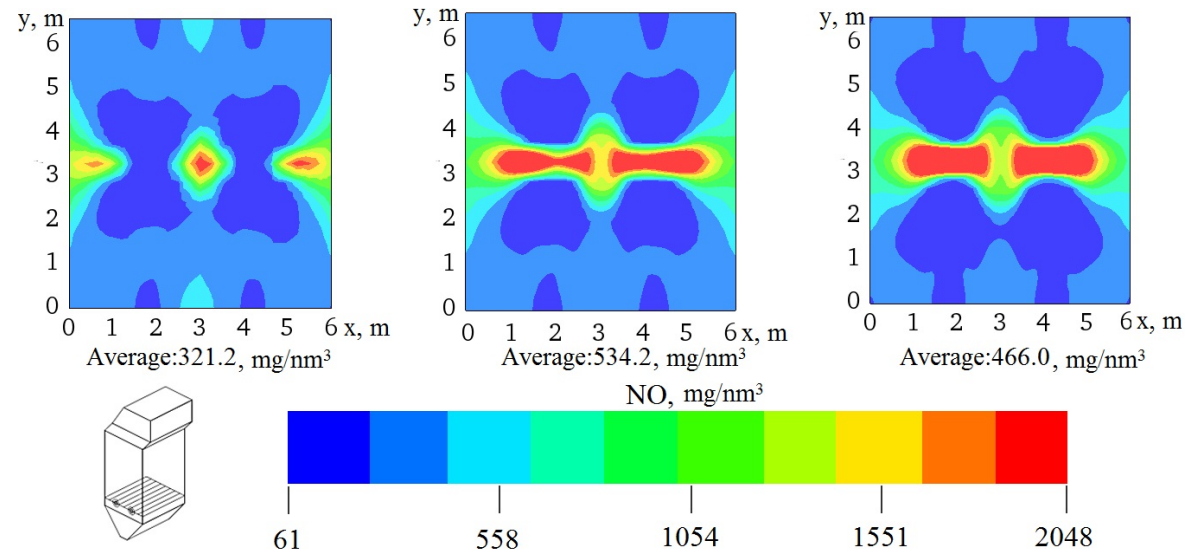

FIGURE 11. The distribution of the concentration of nitrogen oxide NO in the area of the burners for different volumes of air supplied through OFA injectors: a) OFA $=0 \%$ (basic version), b) OFA $=10 \%$, c) OFA $=18 \%$.

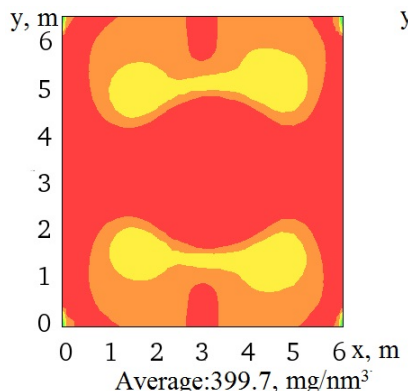

Average: $399.7, \mathrm{mg} / \mathrm{nm}^{3}$

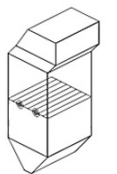

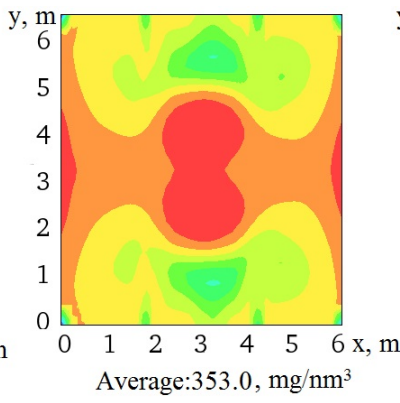

$\mathrm{NO}, \mathrm{mg} / \mathrm{nm}^{3}$
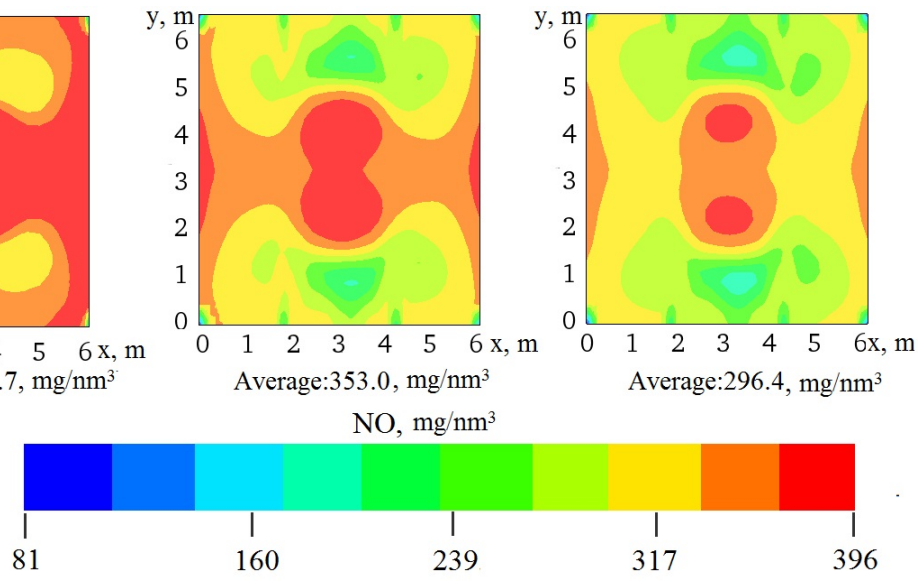

FIgURE 12. The distribution of the concentration of nitrogen oxide NO in the area of OFA injectors at various percentages of air supplied through injectors: a) OFA $=0 \%$ (basic version), b) OFA $=10 \%$, c) OFA $=18 \%$.

a change in the overal velocity vector, temperature $T$, and the concentration of carbon oxides $\mathrm{CO}$ and nitrogen NO over the entire volume of the combustion chamber and at its exit.

As the percentage of air supplied through the OFA nozzles increases, the temperature in the region of the belt zone of the burners of the combustion chamber increases. This is due to the fact that, in this case, the area of the burners is depleted in oxygen, which leads to a decrease in the coefficient of excess air. On the contrary, in the area of the location of OFA injectors, the temperature decreases.

It was shown that an increase in the percentage of air supplied through OFA injectors to $18 \%$ leads to a decrease in the concentrations of carbon oxide $\mathrm{CO}$ by about $36 \%$ and nitrogen oxide NO by $25 \%$ when compared with the base case.

The results of computational experiments on the combustion of pulverized coal in the combustion chamber of the BKZ-75 boiler were compared with experimental data obtained in the course of field experiments conducted directly at the operating Shakhtinskaya TPP and with a theoretical temperature value calculated by the CBTI method for the basic version.
The results will optimize the combustion of lowgrade fuel in the combustion chamber of the BKZ-75 boiler, increase the efficiency of fuel burnout, reduce harmful emissions and introduce OFA technology at other coal-burning thermal power plants.

\section{ACKNOWLEDGEMENTS}

This work was supported by the Ministry of Education and Science of the Republic of Kazakhstan No. BR05236730, No.AP05132988 and No.AP05133590.

The author, P. Safarik, expresses thanks for the support by the Project No. CZ.2.16/3.1.00/21569 Centre 3D Volumetric Anemometry.

\section{REFERENCES}

[1] A. Gómez, C. Dopazo, N. Fueyo. The causes of the high energy intensity of the Kazakh economy: A characterization of its energy system. Energy 71:556 568, 2014. DOI:10.1016/j.energy.2014.04.102

[2] R. K. Manatbayev, V. Y. Maksimov, et al. The computational study of heat and mass transfer processes at combustion of pulverized Kazakh coal in real conditions of energy objects. Bulgarian Chemical Communications 50:61 - 67, 2018. 
[3] A. Askarova, A. Bekmukhamet, S. Bolegenova, et al. 3 -D modeling of heat and mass transfer during combustion of solid fuel in Bkz-420-140-7C combustion chamber of Kazkhstan. Journal of Applied Fluid Mechanics 9(02):699 - 709, 2016. DOI:10.18869/acadpub.jafm.68.225.22881

[4] H. Muller, R. Leithner, A. Magda, et al. Combustion of low-rank coals in furnaces of Kazakhstan coal-firing power plants. VDI Berichte pp. 497 - 502, 2007.

[5] M. T. Beketayeva, S. A. Bolegenova, et al. Computational method for investigation of solid fuel combustion in combustion chambers of a heat power plant. High Temperature 53(5):751 - 757, 2015.

[6] A. Askarova, A. Yergalieva, et al. Simulation of the aerodynamics and combustion of a turbulent pulverized-coal flame. In 4th International Conference on Mathematics and Computers in Sciences and in Industry (MCSI), pp. 92 - 97. 2017.

[7] A. Askarova, S. Bolegenova, V. Maximov, et al. Control of harmful emissions concentration into the atmosphere of megacities of Kazakhstan republic. IERI Procedia 10:252 - 258, 2014. DOI:10.1016/j.ieri.2014.09.085.

[8] A. S. Askarova, S. A. Bolegenova, P. Safarik, et al. Modern computing experiments on pulverized coal combustion processes in boiler furnaces. News of the national academy of sciences of the Republic of Kazakhstan-series physico-mathematical 6(322):5 - 14, 2018.

[9] M. Buchmann, et al. Structure of the flame of fluidized-bed burners and combustion processes of high-ash coal. Gesell Energietech, Combustion and Incineration 1313:241 - 244, 1997. In Proceedings of the18th Dutch-German Conference on Flames.

[10] P. Šafařík, et al. Investigation of heat and mass transfer processes in the combustion chamber of industrial power plant boiler. Part 2. Distribution of concentrations of $\mathrm{O} 2, \mathrm{CO}, \mathrm{CO} 2, \mathrm{NO}$. Applied and Computational Mechanics 12(2):127 - 138, 2018.

[11] S. Bolegenova, et al. 3D modelling of heat and mass transfer processes during the combustion of liquid fuel. Bulgarian Chemical Communications 48:229 - 235, 2016.

[12] S. Bolegenova, R. Leithner, A. Askarova, et al. Computational modeling of heat and mass transfer processes in combustion chamber at power plant of kazakhstan. MATEC Web of Conferences 76:06001, 2016. DOI:10.1051/matecconf/20167606001

[13] M. Gorokhovski, A. Chtab-Desportes, I. Voloshina, A. Askarova. Stochastic simulation of the spray formation assisted by a high pressure. AIP Conference Proceedings 1207(1):66 - 73, 2010. DOI:10.1063/1.3366446

[14] A. Askarova, S. Bolegenova, A. Bekmukhamet, et al. Using 3D modeling technology for investigation of conventional combustion mode of BKZ-420-140-7C combustion chamber. Journal of Engineering and Applied Sciences 9:24 - 28, 2014. DOI:10.3923/jeasci.2014.24.28.

[15] A. Askarova, S. Bolegenova, V. Maximov, A. Bekmuhamet. Mathematical simulation of pulverized coal in combustion chamber. Procedia Engineering 42:1150 - 1156, 2012. DOI:10.1016/j.proeng.2012.07.507
[16] I. Bukovský, M. Kolovratník. A neural network model for predicting NOx at the Melnik 1 coal-powder power plant. Acta Polytechnica 52(03):17 - 22, 2012.

[17] K. S. Baktybekov, et al. Investigation of the different Reynolds numbers influence on the atomization and combustion processes of liquid fuel. Bulgarian Chemical Communications 50:68 - 77, 2018.

[18] S. Bolegenova, et al. Numerical modeling of burning pulverized coal in the combustion chamber $\mathrm{f}$ the boiler PK 39. News of the national academy of sciences of the Republic of Kazakhstan-series physico-mathematical 2(312):58 - 63, 2017.

[19] Z. Baizhuma, et al. The use of a new "clean" technology for burning low-grade coal in on boilers of Kazakhstan TPPs. News of the national academy of sciences of the Republic of Kazakhstan-series physico-mathematical 50:53 - 60, 2018.

[20] E. I. Karpenko, V. E. Messerle, A. Ustimenko, et al. Plasma enhancement of combustion of solid fuels. High Energy Chemistry 40(2):111 - 118, 2006. DOI:10.1134/S0018143906020081.

[21] P. Šafařík, et al. 3D modeling of combustion thermochemical activated fuel. News of the national academy of sciences of the Republic of Kazakhstan-series physico-mathematical 2(324):9 - 16, 2019.

[22] V. E. Messerle, A. S. Askarova, A. B. Ustimenko, et al. Optimization of the combustion of power station coals using plasma techologies. Journal Thermal Engineering 51:488 - 493, 2004.

[23] V. E. Messerle, A. S. Askarova, S. A. Bolegenova, et al. 3D-modelling of Kazakhstan low-grade coal burning in power boilers of thermal power plant with application of plasma gasification and stabilization technologies. Journal of Physics: Conference Series 1261:012022, 2019. DOI:10.1088/1742-6596/1261/1/012022

[24] M. Kuang, Z. Li, X. Jing, et al. Characterization of combustion and NOx emissions with respect to overfire air damper opening in a down-fired pulverized-coal furnace. Energy \& Fuels 27:5518 - 5526, 2013. DOI:10.1021/ef401205k

[25] W. Fan, Z. Lin, Y. Li, M. Zhang. Experimental flow field characteristics of OFA for large-angle counter flow of fuel-rich jet combustion technology. Applied Energy 87(8):2737 - 2745, 2010. DOI:10.1016/j.apenergy.2010.02.012

[26] T. Hunt, L. Muzio, R. Smith, T. J. Hanley. Integrating low-NOx burners, overfire air, and selective non-catalytic reduction on a utility coal-fired boiler. Environmental Progress 14(2):115-120, 1995. DOI:10.1002/ep.670140215

[27] A. S. Askarova, S. A. Bolegenova, A. N. Aldiyarova, et al. Mathematical modelling of heat and mass transfer in the presence of physical chemical processes. Bulgarian Chemical Communications 48(E):272 - 277, 2016.

[28] V. V. Gordeev, Y. M. Salomasov. Two-stage burning of high-ash Ekibastuz coal on a modernized boiler PK-39-2M of 325 MW power unit (station No. 2) of the power plant of AEC "AEC" in Aksu Kazakhstan. In XIII All-Russian conference "Combustion of solid fuel", pp. 92.1 - 92.9. 2012. 
[29] A. Askarova, V. Messerle, A. Ustimenko, et al. Reduction of noxious substance emissions at the pulverized fuel combustion in the combustor of the BKZ-160 boiler of the Almaty heat electropower station using the "Overfire Air" technology. Thermophysics and Aeromechanics 23:125 - 134, 2016. DOI:10.1134/S0869864316010133.

[30] J. Štefanica, J. Hrdlička. Nox prediction for FBC boilers using empirical models. Acta Polytechnica 23(1):68 - 73, 2014.

[31] P. Bennet. Nox prediction research report 20. Tech. rep., Research Centre for Black Coal Utilization, 2001.

[32] M. S. Roni, S. Chowdhury, S. Mamun, et al. Biomass co-firing technology with policies, challenges, and opportunities: A global review. Renewable and Sustainable Energy Reviews 78:1089 - 1101, 2017. DOI:10.1016/j.rser.2017.05.023.

[33] W. Yang, B. Wang, S. Lei, et al. Combustion optimization and NOx reduction of a $600 \mathrm{MWe}$ down-fired boiler by rearrangement of swirl burner and introduction of separated over-fire air. Journal of Cleaner Production 210:1120 - 1130, 2019. DOI:10.1016/j.jclepro.2018.11.077

[34] A. Milićević, S. Belošević, N. Crnomarković, et al. Mathematical modelling and optimisation of lignite and wheat straw co-combustion in 350 MWe boiler furnace. Applied Energy 260:114206, 2020. DOI:10.1016/j.apenergy.2019.114206

[35] R. Leithner, E. I. Heierle, et al. Cfd code florean for industrial boilers simulations. WSEAS Transactions on Heat and Mass Transfer 4(4):98 - 107, 2009.

[36] S. Bolegenova, et al. CFD study of harmful substances production in coal-fired power plant of Kazakhstan. Bulgarian Chemical Communications 48(E):260 - 265, 2016.

[37] R. Leithner. Numerical Simulation. Computational Fluid Dynamics CFD: Course of Lecture. Braunschweig: IWBT, 2006.

[38] A. Askarova, V. Maximov, S. Bolegenova, et al. Numerical investigation of heat and mass transfer processes in the combustion chamber of industrial power plant boiler. Part 1. Flow field, temperature distribution, chemical energy distribution. Applied and Computational Mechanics 11:115 - 128, 2017. DOI:10.24132/acm.2017.395.

[39] M. Beketayeva, S. A. Bolegenova, A. Askarova, V. Maximov. Influence of boundary conditions to heat and mass transfer processes. International Journal of Mechanics 10:320 - 325, 2016.
[40] A. S. Askarova, S. Bolegenova, V. Maximov, et al. 3 -D modeling of heat and mass transfer process during the combustion of solid fuel in a swirl furnace. Acta Polytechnica 59(6):543 - 553, 2019. DOI:10.14311/AP.2019.59.0543

[41] V. Messerle, A. Askarova, S. Bolegenova, et al. Processes of heat and mass transfer in furnace chambers with combustion of thermochemically activated fuel. Thermophysics and Aeromechanics 26:925 - 937, 2019. DOI:10.1134/S0869864319060143

[42] R. Leithner, H. Muller. CFD studies for boilers. In Second M.I.T. Conference on Computational Fluid and Solid Mechanics, pp. 172 - 180. 2003.

[43] A. S. Askarova, S. A. Bolegenova, V. Y. Maksimov, et al. Numerical research of aerodynamic characteristics of combustion chamber BKZ-75 mining thermal power station. Procedia Engineering 42:1250 - 1259, 2012. DOI:10.1016/j.proeng.2012.07.517.

[44] A. Askarova, S. Bolegenova, V. Maximov, M. Beketayeva. Modeling of heat mass transfer in high-temperature reacting flows with combustion. High Temperature 56:738 - 743, 2018. DOI:10.1134/S0018151X1805005X

[45] A. S. Askarova, S. A. Bolegenova, P. Safarik, et al. 3D modeling of heat transfer processes in the combustion chamber of a TPP boiler. News of the national academy of sciences of the Republic of Kazakhstan-series physico-mathematical 6(328):5 - 13, 2019.

[46] A. Askarova, S. Bolegenova, S. Bolegenova, et al. Simulation of low-grade coal combustion in real chambers of energy objects. Acta Polytechnica 59(2):98 - 108, 2019. DOI:10.14311/AP.2019.59.0098.

[47] P. Safarik, A. S. Askarova, S. Bolegenova, et al. Optimization of the solid fuel combustion process in combustion chambers in order to reduce harmful emissions. News of the national academy of sciences of the Republic of Kazakhstan-series physico-mathematical 6:34 - 42, 2019. DOI:10.32014/2019.2518-1726.71.

[48] A. S. Askarova, S. A. Bolegenova, S. A. Bolegenova, et al. 3D modeling of the aerodynamics and heat transfer in the combustion chamber of the BKZ-75 boiler of the Shakhtinsk cogeneration plant. Thermophysics and Aeromechanics 26:295 - 311, 2019. DOI:10.1134/S0869864319020124

[49] B. K. Aliyarov, M. B. Aliyarov. Burning kazakhstan coal at thermal power plants and large boiler houses: Experience and Problems. Gylym ordasy, Almaty, 2012.

[50] Thermal calculation of boilers. Normative method, Publishing House AOOT "NCPO CKTI", 1998. 